\title{
First Results of Monitoring the New Invasive Species Prunus serotina Ehrh. Population inside the Regeneration Area of Common Oak-Hornbeam Forest in Western Croatia
}

\author{
Jasnica Medak ${ }^{1}$, Sanja Perić ${ }^{2}$, Nikola Zorić ${ }^{3}$, Ivana Sirovica ${ }^{1, *}$
}

(1) Croatian Forest Research Institute, Division for Forest Ecology, Cvjetno naselje 41, HR-10450 Jastrebarsko, Croatia; (2) Croatian Forest Research Institute, Director, Cvjetno naselje 41, HR-10450 Jastrebarsko, Croatia; (3) Croatian Forest Research Institute, Division for Forest Protection and Game Management, Cvjetno naselje 41, HR-10450 Jastrebarsko, Croatia

* Correspondence: e-mail: ivanas@sumins.hr

\begin{abstract}
Citation: Medak J, Perić S, Zorić N, Sirovica I, 2021. First Results of Monitoring the New Invasive Species Prunus serotina Ehrh. Population inside the Regeneration Area of Common OakHornbeam Forest in Western Croatia. South-east Eur for 12(2): 135-142. https://doi.org/10.15177/seefor.21-17. Received: 26 Oct 2021; Revised: 13 Dec 2021; Accepted: 14 Dec 2021; Published online: 21 Dec 2021
\end{abstract}

\begin{abstract}
Black cherry (Prunus serotina Ehrh., Rosaceae) is a widespread invader of the European temperate forests and a significant component of the human-caused part of the global environmental changes. Its successful invasion results from a complex interaction between the species life traits and the recipient ecosystem attributes. While it has been recorded to develop spontaneously in numerous European countries, in Croatia information details on its population distribution, as well as its current status, are still missing. The individuals of $P$. serotina were found in the pedunculate oak (Quercus robur L.) forest regeneration area of Jastrebarsko forest management unit in 2018. This alerted us to start to monitor its spreading area, status and impact on the native plant species in a four-year period (2018-2021). In order to investigate the habitat characteristics, phytosociological approach was applied. In addition, the area was surveyed using an unmanned aerial vehicle (UAV) DJI Mavic 2 Pro and DJI Ground Station Pro. The results showed that $P$. serotina spread considerably in the regeneration area, which indicates its invasive character. It also caused alteration in current vegetation. Fast initial expansion of $P$. serotina in 2019 was slowed down in the next 2 years due to performed tending activities, suggesting mechanical measures could help to control its invasive spreading at an early stage of development. This research brought up the first record of the Prunus serotina species in pedunculate oak forest regeneration area of western Croatia with a recommendation to continue the monitoring survey in order to help prevent its spread in the future.
\end{abstract}

Keywords: regeneration area monitoring; invasiveness; Jastrebarsko; spreading control; phytosociology; forest management

\section{INTRODUCTION}

Alien invasive species, i.e. the species that are not native to a specific location (an introduced species), are nowadays recognized as the second most important cause of biodiversity loss (just after direct habitat destruction) and may have a strong wide-ranging environmental (on structure, function and stability of the ecosystem) and an economic impact (Starfinger 1991, Simberloff et al. 2013). From an extensive literature on biological invasions (e.g.
Starfinger 1991, Starfinger 1997, Vitousek et al. 1997, Everett 2000, Kolar 2001, Vila and Weiner 2004, Godefroid 2005, Verheyen et al. 2007, Vila et al. 2010, Simberloff et al. 2013, Aerts et al. 2017), it can be seen that an organism introduction to areas where they were originally absent may have very different consequences. In the vast majority of cases the introduced species do not survive in the natural or near-natural vegetation and only a small percentage totally naturalizes. In other cases, new species do not only naturalize successfully, but also significantly change the 
whole ecosystem This happens mostly by establishing high abundance, affecting the regeneration of the native species by suppressing their growth (Huxel 1999, Godefroid 2005, Vanhellemont et al. 2010), indirectly changing the plant community composition and affecting belowground carbon pools (Ehrenfeld 2004, Koutika et al. 2007). They can also have a direct impact on human health, for instance by producing allergenic pollen that exacerbate respiratory diseases or just by serving as a novel habitat for disease vectors (Vitousek et al. 1997). Invasive species often affect larger areas and their impacts on plant communities and soil microbiota may accelerate or decelerate the local nutrient cycles (Ehrenfeld 2003, Vanderhoeven et al. 2005, Liao et al. 2007, Dassonville et al. 2008, Lazzaro et al. 2014), promoting losses or gains in local nutrient stocks and even have an impact on the greenhouse gas emissions from the soil (Wayne et al. 2002, Chen et al. 2015).

American bird cherry, black cherry or rum cherry (Prunus serotina Ehrh.) is a deciduous, single-stemmed, native forest tree originating from dry and warm parts of the North America, which was introduced and successfully spread across Europe. It typically forms large and straight branchfree boles and narrow crowns in the forest environment and an irregular crown type with short and broad trunks in the opening area. The bark of the young stems is thin, smooth and reddish-brown to nearly black, while the bark of the large trunks is fissured and scaly but remains thin. It develops simple, elliptic-ovate, thick and glossy leaves with serrated leaf margins, two green glands on the petiole and a brown tomentose center leaf vein. Its small, white and 5-petalled flowers with a pleasant smell form long, cylindrical inflorescences, while the incoming fruits are nearly globular, one-seeded, purplish-black to black, edible drupes (Muys et al. 1992, Starfinger 2010). Prunus serotina is highly resistant to some less favorable ecological factors for the majority of the plant species such as drought, frost, lack of light, and excess moisture. It prefers moderately acidic habitats of deep, humid soils with moderate nitrogen concentrations and can also grow on somewhat poorer soils such as sandy or salty ones. Prunus serotina shows resistance to various pollutions and even to the pesticide effects of the certain repellents. Its incredibly high hardiness ability and tendency to easily produce larger amount of seeds allows it to successfully expand and have an impact on various types of ecosystems (Muys et al. 1992, Starfinger 2010, Thijs et al. 2012). P. serotina disperses by seeds but has a very efficient asexual reproduction by suckering and sprouting. If it is sufficiently exposed to light, it produces an abundant quantity of seeds since the age of seven. Seeds are dispersed by birds and frugivorous mammals (Muys et al. 1992). While its growth rate and/or mass seed production is approximately proportional to light availability, P. serotina also holds competitive advantage of enabling its seedlings to persist as ageing juveniles in the dense shade conditions, giving itself the opportunity to disperse again in more favorable, open-gap conditions (Closset-Kopp et al. 2007).

Studies on the invasion of $P$. serotina and its effects have been published by many researchers (Bijak et al. 2014, Halarewicz et al. 2014, Aerts et al. 2017). According to the European alien species checklist database (Klotz 2007),
P. serotina takes place as an invasive plant species with an existing evidence on various impacts (environmental, social and/or economic) in Europe (Klotz 2007, Kettunen et al. 2009, Sitzia et al. 2016). It covers large parts of the continental European lowlands, reaching high abundance and invasive status in Germany, especially the northern half of the country (Kowarik 1995), the Netherlands (Klotz 2007, Vanhellemont et al. 2010), Denmark (Andersen 1995), Poland (Bijak et al. 2014), Belgium (Godefroid et al. 2005, Vanhellemont 2009, Vanhellemont et al. 2010), Switzerland (Wittenberg 2005), the Czech Republic (Vanhellemont 2009, Pyšek et al. 2012) and Southern England (CABI Undated, EPPO Global Database 2020).

In accordance with the European regulation on Invasive Alien Species (IAS), the black cherry tree has recently been indicated as one of the 96 species proposed for the development of the national list of priority invasive alien species in Italy (Forte et al. 2019). In Slovenia, on the other hand, current status has not been yet extensively studied. As far as it is known, only few places are currently naturalized with an invasive tendencies (LIFE ARTEMIS, Undated).

Furthermore, the existing data from Nikolić 2005 (Flora Croatica Database) indicate the presence of $P$. serotina species in some parts of Croatia (Figure 1). P. serotina occurrence has been recorded in Arboretum Lisičine (Idžojtić et al. 2011) as well as in Đurđevački peski Arboretum (Ređep 2017). The data on its distribution within forest complexes and natural habitats are still missing. Unlike in many European countries, in Croatia $P$. serotina is still not on the invasive species list.

Also, according to the EPPO Global Database $P$. serotina observation point, the presence of $P$. serotina in Croatia still lacks the information details (https://gd.eppo.int/taxon/ PRNSO/distribution/HR). Lack of national inventories of $P$. serotina populations emphasizes the importance of its further monitoring in our area.

This paper deals with the possible invasiveness of the black cherry in Croatia. Due to its fast growing capability and

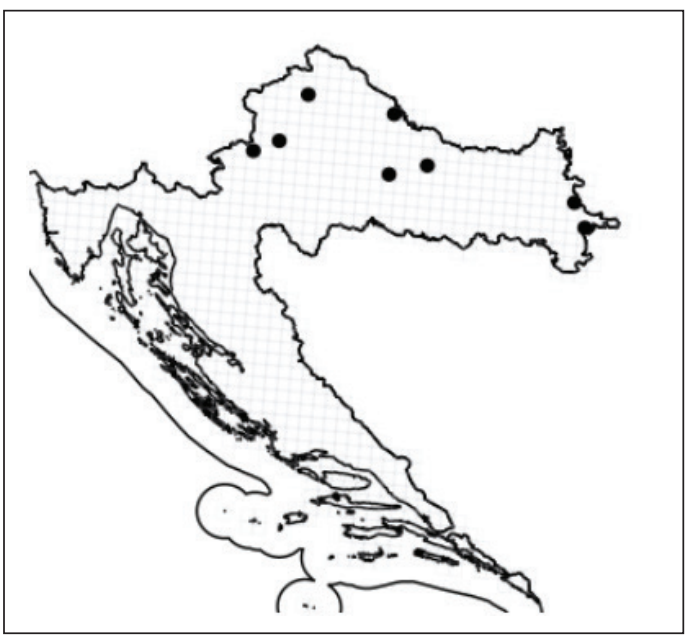

Figure 1. Current data of $P$. serotina's presence in Croatia (https://hirc.botanic.hr/fcd/). 
the potential to establish dense shrub layer in sparse forests, it may outcompete some native plant species and become the source or decreasing biodiversity. Its significant spread in pedunculate oak forest regeneration area motivated us to find the most adequate way of tracking its further expansion and development.

The objectives are to determine its spreading area, status and its impact on the native plant species by monitoring over a certain period of time.

\section{MATERIALS AND METHODS}

A research area of the $P$. serotina distribution is located in the Jastrebarsko Forest Office as part of the management unit of "Jastrebarske prigorske šume" and subcompartment 19a with the total size of 11.73 ha (Figure 2).

The research area is a former forest culture that consisted of Weymouth pine (Pinus strobus) as main species together with Scots pine ( $P$. sylvestris) and Norway spruce (Picea abies). The area was affected with two mayor windbreaks in 2014 and 2016, resulting with more openings in the canopy layer and degradation of forest structure and habitat. This ended up in 2017 with the replantation of pedunculate oak (Quercus robur L.) seedlings inside polypropylene tree shelters in the amount of 8000 seedlings per 4 ha.

According to Köppen climate classification, the area belongs to the "Cfwbx" type of climate. This indicates moderately warm, rainy climate where the mean temperature of the coldest month in the year is between $-3^{\circ} \mathrm{C}$ and $18^{\circ} \mathrm{C}$ and the warmest is between $10^{\circ} \mathrm{C}$ and $22^{\circ} \mathrm{C}$. The surrounding forest area belongs to Carpino betuliQuercetum roboris (Anić 1959, Rauš 1971) with a typical pseudogley soil type. The first dissemination data of the $P$. serotina in this area date from $15^{\text {th }}$ September 2018.

In order to perform area monitoring we did an areal recording four times in 2019-2021 period ( $3^{\text {rd }}$ May and $7^{\text {th }}$ June 2019, on $30^{\text {th }}$ June 2020 and on $16^{\text {th }}$ August 2021). It was performed with the use of the unmanned aerial vehicle (UAV) DJI Mavic 2 Pro equipped with standard RGB sensor. These images were used to determine the size of the affected area with $P$. serotina speciments. The mission was planned with DJI Ground Station Pro app for iOS. It was

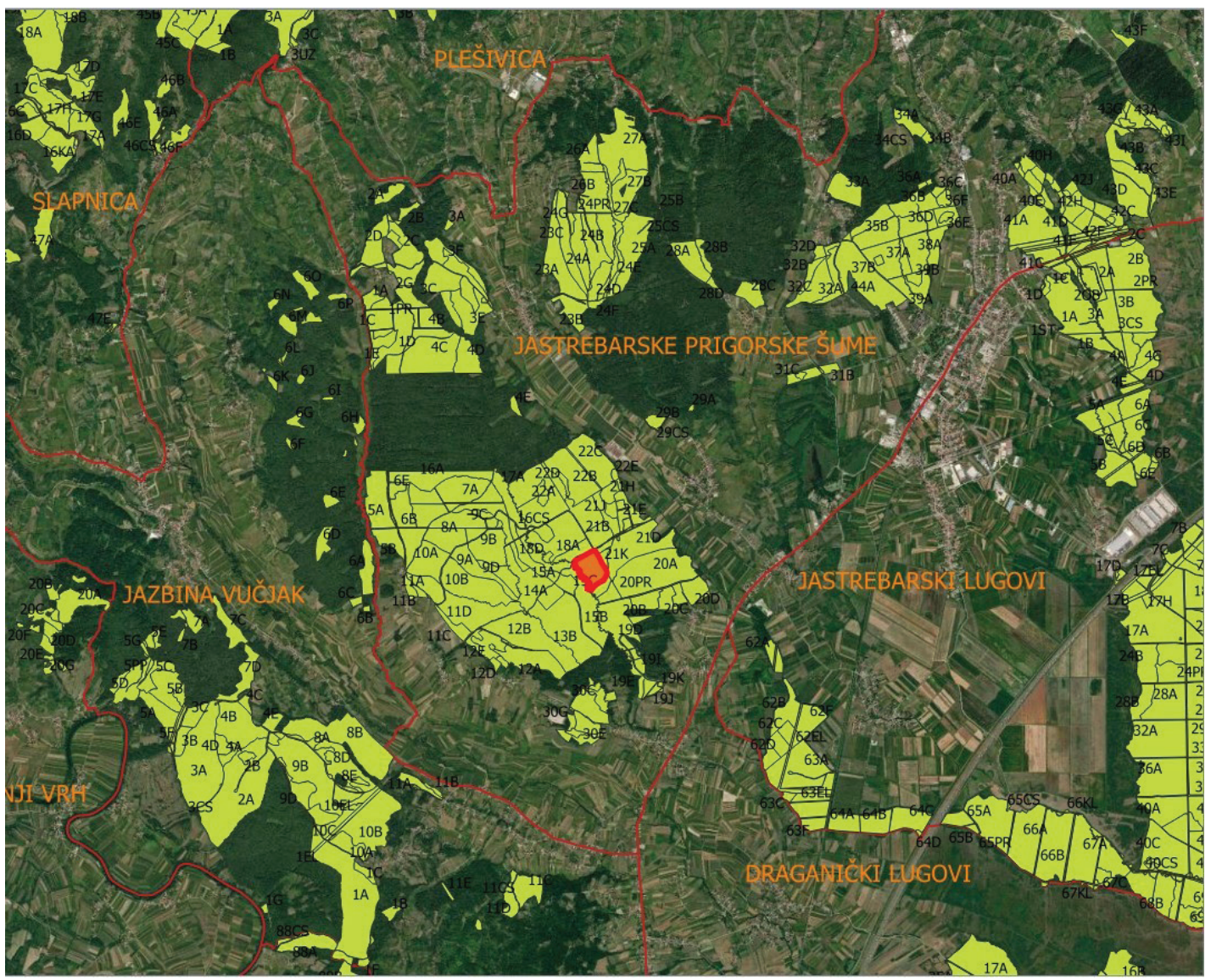

Figure 2. Position of management unit "Jastrebarske prigorske šume". 
conducted with $80 \%$ front overlap ratio and $75 \%$ side overlap which allowed high quality of post flight image processing. The above ground flight was set to 90 meters, resulting with $2.1 \mathrm{~cm}$ pixel resolution. Post flight data processing, which included photos alignment, dense cloud build, mesh build and lastly orthomosaic build, was performed using AgiSoft PhotoScan Professional (Version 1.5.5) software. Map of the area was created using QGIS software (QGIS Development Team, http://qgis.osgeo.org). The size of the area affected by black cherry was calculated with QGIS geometry tools.

In order to research habitat characteristics of the area and possible $P$. serotina invasion, we performed vegetation survey according to the standard Brown-Blanquet method (1964) during the high vegetation season on $27^{\text {th }}$ July 2020 and on $2^{\text {nd }}$ August 2021.

\section{RESULTS}

\section{Spreading Data}

The first report of the $P$. serotina occurrence in forest ecosystem of western Croatia dates from September 2018, when spreading of the "unknown" woody species was detected by local foresters. Herbarium material was collected and brought to Croatian Forest Research Institute where it was identified as $P$. serotina species. The affected area of approximately $200 \mathrm{~m}^{2}$ in 2018 was reported during the stand tending activities.

Based on the conducted research process, the estimated area of the black cherry expanded to $480.75 \mathrm{~m}^{2}$ in 2019. It increased its distribution area considerably in comparison to the reported one in 2018.

After this significant spread, the interpretation of aerial images showed no change in the infested area in 2020 and 2021. Even though further spreading of $P$. serotina was successfully prevented by forest tending activities, mechanical measures did not manage to totally remove $P$. serotina off the regeneration area.

\section{Vegetation Data}

The results of phytosociological survey in the regeneration area affected with $P$. serotina showed that it mostly consists of pioneer and a fast growing, heliophilic flora. As it can be seen in Table 1, the high shrub is mostly overlaid by $P$. serotina (Figure 5).

The herb layer is mostly covered by Solidago gigantea, together with other invasive species such as Phytolacca americana, Ambrosia artemisifolia, Erigeron annuus and other stress-tolerant species: Eupatorium cannabinum and Pteridium aquilinum. In 2021 some species were missing, such as: Abies alba, Calluna vulgaris, Angelica sylvestris, Asarum europaeum, Athyrium filix-femina, Centaurea jacea, Dryopteris filix-mas, Equisetum aquilinum, Fragaria vesca, Glechoma hederacea, Humulus lupulus, Pinus strobus and Pulmonaria officinalis.

Vegetation survey of the surrounding forest area of Carpino betuli-Quercetum roboris community indicates typical floral composition for this community. We detected herbaceous invasive plant species such as Phytolacca americana and Erigeron annuus, but no presence of Prunus serotina specimens.
Table 1. Phytocenological recordings of both regeneration area.

\begin{tabular}{|c|c|c|}
\hline & \multicolumn{2}{|c|}{ Regeneration area } \\
\hline & 2 August 2020 & 27 July 2021 \\
\hline Relevé area $\left(\mathrm{m}^{2}\right)$ & \multicolumn{2}{|c|}{400} \\
\hline Altitude (m) & \multicolumn{2}{|c|}{155} \\
\hline Slope (degrees) & \multicolumn{2}{|c|}{$<10$} \\
\hline Exposure & \multicolumn{2}{|c|}{ SW } \\
\hline
\end{tabular}

\begin{tabular}{|c|c|c|c|}
\hline \multicolumn{2}{|l|}{ Cover tree layer (\%) } & . & . \\
\hline \multicolumn{2}{|l|}{ Cover shrub layer (\%) } & 70 & 70 \\
\hline \multicolumn{2}{|l|}{ Cover herb layer (\%) } & 70 & 70 \\
\hline X-coordinate & & & \\
\hline Y-coordinate & & & \\
\hline Prunus serotina & s1 & 4 & 4 \\
\hline Rubus fructicosus & s1 & 2 & 2 \\
\hline Quercus robur & s1 & 1 & 1 \\
\hline Carpinus betulus & s1 & 1 & 1 \\
\hline Salix caprea & s1 & 1 & 1 \\
\hline Frangula alnus & s1 & + & 1 \\
\hline Populus alba & s1 & + & 1 \\
\hline Abies alba & s1 & + & . \\
\hline Pinus strobus & s1 & + & + \\
\hline Populus tremula & s1 & + & + \\
\hline Alnus glutinosa & s1 & + & + \\
\hline Solidago gigantea & $\mathrm{hl}$ & 2 & 2 \\
\hline Eupatorium cannabinum & $\mathrm{hl}$ & 2 & 2 \\
\hline Phytolacca maericana & $\mathrm{hl}$ & 1 & 1 \\
\hline Pteridium aquilinum & $\mathrm{hl}$ & 1 & 1 \\
\hline Calluna vulgaris & $\mathrm{hl}$ & 1 & . \\
\hline Genista tinctoria & $\mathrm{hl}$ & 1 & + \\
\hline Ambrosia artemisifolia & $\mathrm{hl}$ & + & + \\
\hline Angelica sylvestris & hl & + & . \\
\hline Asarum europaeum & $\mathrm{hl}$ & + & . \\
\hline Athyrium filix-femina & $\mathrm{hl}$ & + & . \\
\hline Calamagrostis epigejos & $\mathrm{hl}$ & + & + \\
\hline Carpinus betulus & $\mathrm{hl}$ & . & + \\
\hline Centaurea jacea & $\mathrm{hl}$ & + & . \\
\hline Cirsium palustre & $\mathrm{hl}$ & + & + \\
\hline Dryopteris filix-mas & $\mathrm{hl}$ & + & . \\
\hline Equisetum sylvaticum & hl & + & . \\
\hline Erigeron annuus & $\mathrm{hl}$ & + & + \\
\hline Fragaria vesca & $\mathrm{hl}$ & + & . \\
\hline Glechoma hederacea & $\mathrm{hl}$ & + & . \\
\hline Humulus lupulus & hl & + & . \\
\hline Juncus effusus & $\mathrm{hl}$ & + & + \\
\hline Lycopus europaeus & $\mathrm{hl}$ & + & + \\
\hline Lysimachia vulgaris & $\mathrm{hl}$ & + & + \\
\hline Lythrum salicaria & $\mathrm{hl}$ & + & + \\
\hline Pinus strobus & $\mathrm{hl}$ & . & . \\
\hline Potentilla erecta & $\mathrm{hl}$ & + & + \\
\hline Pulmonaria officinalis & $\mathrm{hl}$ & + & . \\
\hline Salix caprea & $\mathrm{hl}$ & . & + \\
\hline Scrophularia nodosa & $\mathrm{hl}$ & + & + \\
\hline Tanacetum vulgare & $\mathrm{hl}$ & + & + \\
\hline Viola reichenbachiana & $\mathrm{hl}$ & + & + \\
\hline
\end{tabular}




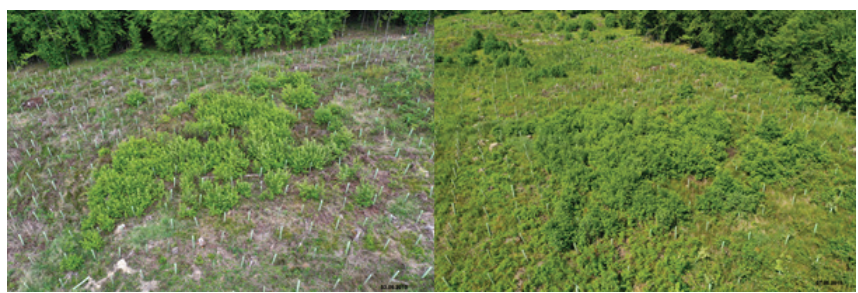

Figure 3. Black cherry group in subcompartment 19a in May and June 2019.

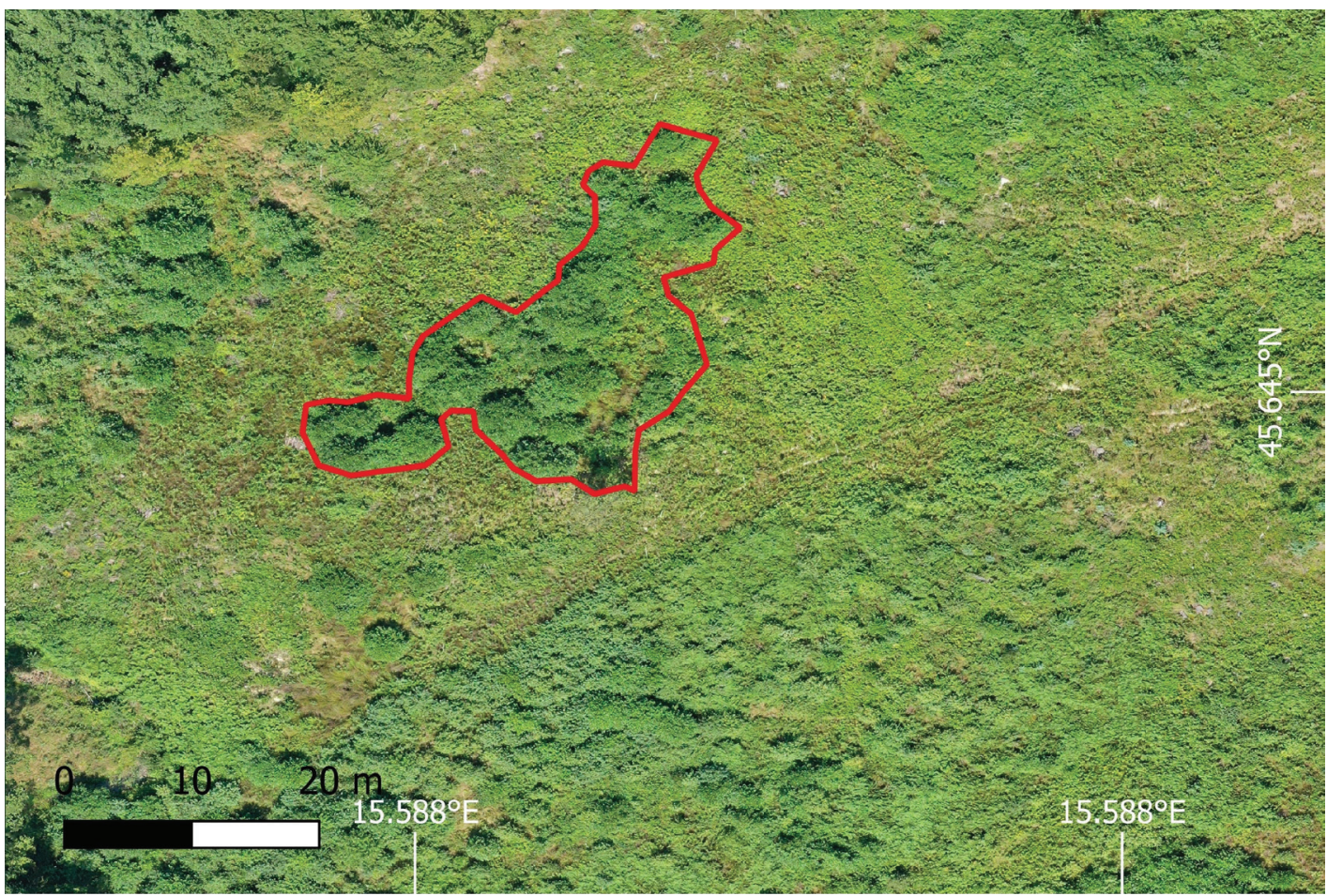

Figure 4. Size of the affected area by P. serotina.

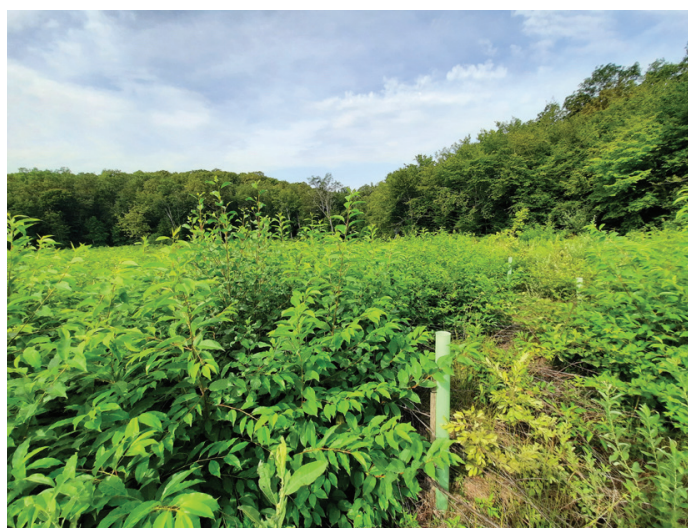

Figure 5. Rapid P. serotina development suppresses growth of other species.

\section{DISCUSSION}

Structural complexity and continuous canopy cover represent one of the main characteristics that insure stability of the forest community. When, at some point, this stability is disrupted, both by anthropogenic and/or natural large-scale disturbances ending with a canopy cover fragmentation, the habitat becomes exposed to potential invasive species' development.

This highlights degradation issue which consequently, in the majority of cases, often leads to vitality disruption and invasive species settlement. Also, the ability of $P$. serotina to naturalize in less favourable environmental conditions, as well as not having direct competitors with a similar life strategy, contributes to its successful expansion and domination upon the native species regeneration process (Starfinger 1997). P. serotina's tendency to easily produce abundant quantity of seed and disperse it by birds and 
frugivorous mammals can also allow its appearance and successfully expand in various types of ecosystems (Muys et al. 1992, Starfinger 2010), as well as in the regeneration area.

Although the first record of $P$. serotina in this area dates from 2018 we do not know exactly when the first specimen appeared, but we can assume, according to its spreading size, that it happened several years before, as part of the former forest culture. This has been also confirmed by many researches that presume pre-gap patterns in the understorey, rather than postgap partioning, largely determine gap composition. It refers to a fact that species that are present in the understorey at the time of gap creation (chance occupants) are the ones that fill the open area and not the best adapted species (Fraver et al. 1998, Brokaw 2000, Closset-Kopp et al. 2006). According to the Closset-Kopp et al. 2006, this 'sit-and wait' strategy is quite common among co-occurring tree species in $P$. serotina's native range (e.g. Fagus grandifolia, Quercus alba, Acer pensylvanicum, Tsuga canadensis), but it is almost unknown for tree species of European temperate forests. This life plasticity greatly contributes to $P$. serotina invasiveness and explains its rapid spread in the regeneration area in the first year of monitoring.

After its significant spreading progression in the regeneration area in 2019, the use of visual image interpretation elements (Lillesan et al. 2008) in 2020 and 2021 showed no expansion or reduction in size covered with $P$. serotina specimens.

Since $P$. serotina was continuously subjected to the above-ground removal treatments (partial-cutting) of essentially all shrub and herb layer vegetation with a mulcher, twice a year (at the beginning of spring and in the late summer period), it contributed to stopping the spreading of the species in the last 2 years of our monitoring process.

Even though mechanical measures did not manage to totally remove $P$. serotina specimens off the regeneration area, they represent its spreading control method in the regeneration area. If we consider the number of other cases undergone $P$. serotina's removal (Muys et al. 1992, Van Den Meersschaut et al. 1997, Oosterbann 2005, Annighöfer et al. 2012), when it comes to successful control measures, a combination of often mechanical and chemical methods is used. Mechanical suppression alone, especially by the above-ground biomass removal, has proven inadequate and it is questionable to what extent it would be considered sufficient for its effective suppression in the regeneration area in the future (Muys et al. 1992). Considering such results from different researches, it is also highly important to continue the monitoring of the spreading area in the pedunculate oak regeneration area.

Vegetation survey of the area affected by $P$. serotina showed the expected presence of regeneration area species such as Rubus fruticosus, Salix caprea, Populus alba, Frangula alnus and high abundance of $P$. serotina in the shrub layer in both 2020 and 2021. Although invasive species (Phytolacca americana, Ambrosia artemisifolia, Erigeron annuus, Solidago gigantea) did not increase their cover significantly, their population became denser and more vigorous after tending activities. Possibly, this lead to repression of some habitat-specific species (Asarum europaeum, Athyrium filixfemina, Dryopteris filix-mas, Equisetum aquilinum, Fragaria vesca, Glechoma hederacea, Pulmonaria officinalis), in just one year.

Vegetation survey of the surrounding Carpino betuliQuercetum roboris forest community reflects the structural stability regarding canopy cover as well as the floristic composition, without the presence of $P$. serotina specimens. Although some researches suggest possibilities of $P$. serotina to invade the natural forest ecosystems (Closset-Kopp et al. 2007, Bijak et al. 2014), we assume that the stability of the forest ecosystem with continuous canopy cover layer is the first and crucial point in fighting invasive plant species.

\section{CONCLUSIONS}

This research brought up the first record of Prunus serotina species in pedunculate oak forest regeneration area of western Croatia. Initial significant expansion of the $P$. serotina specimens in the first year of monitoring process indicated its invasive character. $P$. serotina needs to be put on the Croatian National Invasive Species list. The other two-year vegetation survey monitoring showed no change in $P$. serotina spreading. This does not only relate to $P$. serotina, but to other invasive and non-invasive species as well. Mechanical measures, in this case, as a part of a regularly conducted tending activities, represent a potential spreading control method of $P$. serotina. This method of monitoring by using the unmanned aerial vehicle with basic RGB sensors showed the possibility for a fast and easy detection of species. This can also be used for fast on-site inspection of other large areas at a low cost. We recommend to continue the monitoring survey of $P$. serotina in order to prevent and control its spread in the future.

\section{Author Contributions}

$\mathrm{JM}$ and SP conceived and designed the research. JM, IS and NZ carried out the field activities, NZ processed the data and performed area surveying while JM and IS performed phytosociological approach. JM and SP secured the research funding and JM supervised the research. JM and IS and NZ wrote the manuscript. JM helped to draft the manuscript.

\section{Funding}

This research has been fully supported by the Croatia Forest Research institute.

\section{Conflicts of Interest}

The authors declare no conflict of interest. 


\section{REFERENCES}

Aerts R, Ewald M, Nicolas M, Piat J, Skowronek S, Lenoir J, 2017. Invasion by the Alien tree Prunus serotina Alters Ecosystem Functions in a Temperate Decidous Forest. Front Plant Sci 14(8): 179. https://doi.org/10.3389/fpls.2017.00179.

Andersen UV, 1995. Comparision of dispersal strategies of alien and native species in the Danish flora. Plant invasions: general aspects and special problems. Kostelec nad Černými lesy, Czech Republic, pp 16-19.

Annighöfer P, Schall P, Kawaletz H, Mölder I, Terwei A, Zerbe S, Ammer C, 2012. Vegetative growth response of black cherry (Prunus serotina) to different mechanical control methods in a biosphere reserve. Can J For For Res 42(12): 2037-2051. https:// doi.org/10.1139/cjfr-2012-0257 2012.

Invasive Species In Belgium, 2014. Prunus serotina. Available online: http://ias.biodiversity.be/species/show/14 (15 July 2021).

Bijak S, Czajkowski M, Ludwisiak L, 2014. Occurance of black cherry (Prunus serotina Ehrh.) in the forests in Poland. For Res Pap 75(4): 359-365. https://doi.org/10.2478/frp-2014-0033.

Braun-Blanquet J, 1964. Pflanzensoziologie, Grundzüge der Vegetationskunde. $3^{\text {rd }}$ edn. Springer, Wien-New York, USA, 865 p.

Brokaw N, Busing RT, 2000. Niche versus chance and tree diversity in forest gaps. Trends Ecol Evol 15: 183-187. https://doi. org/10.1016/s0169-5347(00)01822-x.

$\mathrm{CABI}$, Invasive species Compendium. Prunus serotina. Available online: https://www.cabi.org/isc/datasheet/44360 (15 July 2021).

Chen Y, Chen G, Ye Y, 2015. Coastal vegetation invasion increases greenhouse gas emission from wetland soils but also $F$ increases soil carbon accumulation. Sci Tot Environ 526: 19-28. https://doi. org/10.1016/i.scitotenv.2015. 04.077.

Closset-Kopp D, Chabrerie O, Valentin B, Delachapelle H, Decocq G, 2007. When Oskar meets Alice: Does a lack of trade-off in r/K-strategies make Prunus serotina a successful invader of European forests? Forest Ecol Manag 247(1): 120-130. https:// doi.org/10.1016/i.foreco.2007.04.023.

Dassonville N, Vanderhoeven S, Vanparys V, Hayez M, Gruber W, Meerts P, 2008. Impacts of alien invasive plants on soil nutrients are correlated with initial site conditions in NW Europe. Oecologia 157: 131-140. https://doi.org/10.1007/s00442-008-1054-6.

Ehrenfeld GJ, 2004. Implications of Invasive species for Belowground Community and Nutrient Processes. Weed Technol 18: 12321235. https://doi.org/10.1614/0890-037X(2004)018(1232:IOISF B) 2.0.CO;2.

Ehrenfeld JG, 2003. Effects of exotic plant invasions on soil nutrient cycling processes. Ecosystems 6: 503-523. https://doi. org/10.1007/s10021-002-0151-3.

EPPO Global Database, 2020. Prunus serotina (PRNSO). Available online: https://gd.eppo.int/taxon/PRNSO (15 July 2021).

Everett RA, 2000. Patterns and pathways of biological invasions. Biol Conserv 15(5): 177-178. https://doi.org/10.1016/S0169$\underline{5347(00) 01835-8}$

Forte GWT, Brundu G, Celestl-Grapow L, Siniscalco C, Barni E, 2019. Prunus serotina in Italy: a challenging candidate for the national list of priority invasive alien species. Plant Biosysts 900-904. https://doi.org/10.1080/11263504.2019.1666173.

Fraver S, Brokaw NV, Smith AP, 1998. Delimiting the gap phase in the growth cycle of Panamanian forest. J Trop Ecol 14(5): 674-681.

Godefroid S, Phartyal SS, Weyembergh G, Koedam N, 2005. Ecological factors controlling the abundance of non-native invasive black cherry (Prunus serotina) in deciduous forest understory in Belgium. Forest Ecol Manage 210: 91-105. https:// doi.org/10.1016/i.foreco.2005.02.024.

Halarewicz A, Zolnierz L, 2014. Changes in the understory of mixed coniferous forest plant communities dominated by the American black cherry (Prunus serotina Ehrh.). Forest Ecol Manage 313: 9197. https://doi.org/10.1016/i.foreco.2013.11.006.
Hejda M, Pyšek P, Jarošik V, 2009. Impact of invasive plants on the species richness, diversity and composition of invaded communities. J Ecol 97: 393-403. https://doi.org/10.1111/j.13652745.2009.01480.x.

Huxel RG, 1999. Rapid displacement of native species by invasive species: effects of hybridization. Biol Conserv 89: 143-152. https://doi.org/10.1016/S0006-3207(98)00153-0.

Idžojtić M, Zebec M, 2006. Rasprostranjenost pajasena (Ailanthus altissima /Mill./ Swinge) i širenje invazivnih drvenastih neofita u Hrvatskoj. Glas šum pokuse 5: 315-323.

Idžojtić M, Zebec M, Poljak I, 2011. Dendrological and Horticultural Value of Lisičine Arboretum. Croat J For Eng 32(1) 201-203.

Kettunen M, Genovesi P, Gollasch S, Pagad S, Starfinger U, Brink P, 2009. Technical support to EU strategy on invasive alien species (IAS). Brussels, Belgium, 35 p. Available online: https://ec.europa. eu/environment/nature/invasivealien/docs/Kettunen2009 IAS Task\%201.pdf (15 July 2021).

Klotz S, 2007. Prunus serotina Fact Sheet. Delivering Alien Invasive Species Inventories for Europe (DAISIE). Available online: http:// www.europe-aliens.org/pdf/Prunus serotina.pdf (17 July 2021).

Kolar CS, 2001. Progress in invasion biology: predicting invaders. Biol Conserv 16: 199-204. https://doi.org/10.1016/S01695347(01)02101-2.

Koutika LS, Vanderhoeven S, Chapuis-lardy L, Dassonville N, Meerts $P, 2007$. Assessment of changes in soil organic matter after invasion by exotic plant species. Biol Fertil Soils 44: 331-341. https://doi.org/10.1007/s00374-007-0210-1.

Kowarik I, 1995. Time lags in biological invasions with regard to the success and failure of alien species. Plant invasions: general aspects and special problems. SPB Academic Publishing, pp 1538.

Lazzaro L, Giuliani C, Fabiani A, Agnelli AA, Pastorelli R, Lagomarsino $A, 2014$. Soil and plant changing after invasion: the case of Acacia dealbata in a Mediterranean ecosystem. Sci Tot Environ 491-498. https://doi.org/10.1016/i.scitotenv.2014.08.014.

Liao C, Peng R, Luo Y, Zhou X, Wu X, Fang C, 2007. Altered ecosystem carbon and nitrogen cycles by plant invasion: a meta-analysis. New Phytol 177: 706-714. https://doi.org/10.1111/j.14698137.2007.02290.x.

LIFE ARTEMIS. Prunus serotina. Available online: https://www. tujerodne-vrste.info/projekt-life-artemis/.

Muys B, Madelein D, Lust N, 1992. Ecology, practice and policy of black cherry (Prunus serotina Ehrh.) management in Belgium. Silva Gandavensis 57: 28-45. https://doi.org/10.21825/ sg.v57i0.885.

Nikolić T, 2005-onwards. Flora Croatica Database. Prunus serotina Ehrh. distribution in Croatia. Available online: http://hirc.botanic. hr/fcd (17 July 2021).

Online Atlas of the British and Irish Flora. Prunus serotina. Available online: https://www.brc.ac.uk/plantatlas/ (17 July 2021).

Pyšek P, Chytry M, Pergl J, Sadlo J, 2012. Plant invasions in the Czech Republic: current state, introduction, dynamics, invasive species and invaded habitats. Preslia 84(3): 576-630.

Ređep T, 2017. Flora Đurđevačkih pijesaka. MSc Thesis, University of Zagreb, Faculty of Science, Zagreb, Croatia, $57 \mathrm{p}$.

Simberloff D, Martin J, Genovesi P, Maris V, Wardle AD, Aronson J, 2013. Impacts of biological invasions: what's what and the way forward. Biol Conserv 28: 58-66. https://doi.org/10.1016/i. tree.2012.07.013.

Sitzia T, Campagnaro T, Kowarik I, Trentanovl G, 2016. Using forest management to control invasive alien species: helping implement the new European regulation on invasive alien species. Bio Invasions 18: 1-7. https://doi.org/10.1007/s10530-015-0999-8.

Starfinger U, 1991. Population Biology of an Invading Tree Species Prunus serotina. Species Conserv 171-184. 
Starfinger U, 1997. Introduction and naturalization of Prunus serotina in Central Europe. Plant Invasions: studies from North America and Europe. Leiden, The Netherlands, pp 161-171.

Starfinger U, Kowarik I, Rode M, Schepker H, 2003. From desirable ornamental plant to pest to accepted addition to the flora? - the perception of an alien tree species through the centuries. Biol Invasions 5: 323-335. https://doi.org/10.1023/ B:BINV.0000005573.14800.07.

Thijs KW, Brys R, Verboven HAF, Hermy M, 2012. The influence of an invasive plant species on the pollination success and reproductive output of tree riparian plant species. Biol Invasions 14: 355-365. https://doi.org/10.1007/s10530-011-0067-y.

Vanderhoeven S, Dassonville N, Meerts P, 2005. Increased topsoil mineral nutrient concentrations under exotic invasive plants in Belgium. Plant Soil 275: 169-179. https://doi.org/10.1007/ s11104-005-1257-0.

Vanhellemont M, Verheyen K, Keersmaeker L, Vandekerkhove K, Hermy M, 2009. Does Prunus serotina act as an aggressive invader in areas with a low propagule pressure? Biol Invasions 11: 1451-1462.

Vanhellemont M, Wauters L, Baeten L, Bijlsma RJ, Frenne P, Hermy $M, 2010$. Prunus serotina unleashed: invader dominance after 70 years of forest development. Biol Invasions 12: 1113-1124. https://doi.org/10.1007/s10530-009-9529-x.
Verheyen K, Vanhellemont M, Stock T, Hermy M, 2007. Predicting patterns of invasion by black cherry (Prunus serotina Ehrh.) in Flanders (Belgium) and its impact on the forest understorey community. Divers Distrib 13: 487-497. https://doi.org/10.1111/ j.1472-4642.2007.00334.x.

Vilá M, Basnou C, Pyšek P, Josefsson M, Genovesi P, Gollasch S, 2010. How well do we understand the impact of alien species on ecosystem services? A pan-European, cross-taxa assessment. Front Ecol Environ 8: 135-144. https://doi.org/10.1890/080083.

Vilá M, Weiner J, 2004. Are invasive plant species better competitors than native plant species? Evidence from pair-wise experiments. Oikos 105: 229-238. https://doi.org/10.1111/i.00301299.2004.12682.x.

Vitousek MP, D'Antonio MC, Loope LL, Rejmanek M, Westbrooks R, 1997. Introduced species: A significant component of humancaused global change. N Z J Ecology 21(1): 1-16.

Wayne P, Foster S, Connolly J, Bazzaz F, Epstein P, 2002. Production of allergenic pollen by ragweed (Ambrosia artemisifolia L.) is increased in CO2-enriched atmospheres. Ann Allergy Asthma Immunol 88: 279-282. https://doi.org/10.1016/S10811206(10)62009-1.

Wittenberg R, 2005. An inventory of alien species and their threat to biodiversity and economy in Switzerland. CABI Bioscience Switzerland Centre report to the Swiss Agency for Environment, Forests and Landscape, Bern, Switzerland, $155 \mathrm{p}$. 